\title{
Human Rights Abuses in Xinjiang: Perspectives and Responses from the Islamic World and the Middle East
}

\author{
Carson Ezell \\ Harvard University \\ cezell@college.harvard.edu
}

\begin{abstract}
There are significant geographical disparities in activism throughout the world with respect to supporting the Uyghur cause against human rights abuses in the Xinjiang region of China. This paper introduces the history of Chinese rule of the Xinjiang region and examines the ways in which the Uyghur diaspora has spread. It then explores how geographical, cultural, economic, and religious relationships between Xinjiang and segments of the international community impact attitudes and levels of activism in response to recent developments in Xinjiang, particularly focusing on the weaker responses in the Middle East relative to the rest of the Islamic community. It then proposes recommendations for regional stakeholders in Middle Eastern civil society to encourage greater support for the Uyghur community.
\end{abstract}




\section{Introduction}

The Uyghurs are an ethnically Turkic group from Central Asia, about twelve million of whom reside in the Uyghur Autonomous Region (Xinjiang) of China. They are predominantly Sunni Muslims, and they share many customs and traditions with the rest of the Islamic world. Under Chinese rule since 1950, the Uyghurs have faced increasingly violent and oppressive actions by the Chinese government as well as a crackdown on their freedom and culture. While activism to bring awareness and support to the Uyghur cause has been present throughout parts of the Islamic world, particularly where the Uyghur diaspora is strongest, there has not been a strong response in support of the Uyghurs from the Arab world. Despite the hesitancy of many Arab governments and organizations to express solidarity with the Uyghurs against Chinese policies in Xinjiang as is evident within some countries in the Western world, Southeast Asia and Central Asia, Arab media and public opinion is starting to shift to exhibit a greater level of support for the Uyghur cause. If utilized properly, these trends may be able to create greater support for the Uyghurs across the Middle East in the future.

\section{Background}

Throughout history, the Uyghurs have created multiple independent states in the region of Eastern Turkestan, most recently from 1944 until 1949, but the Chinese People's Liberation Army recaptured the region by 1950 . Since then, the region has been known in China as Xinjiang, meaning "new frontier", and it has formally been a part of China. For decades, China encouraged ethnic Han Chinese to relocate to the region, and Uyghurs made up $45.84 \%$ of the Xinjiang population as of the most recent 2010 census. ${ }^{1}$ Despite being formally recognized as an ethnic minority in China, the Uyghurs have experienced severe repression from the Chinese 
government, especially since the launch of the "Strike Hard Campaign Against Violent Terrorism" in May 2014 which sought to root out the "three evil forces" of terrorism, extremism and splitism. ${ }^{2}$ Notably, while some Uyghurs wish to re-establish an independent state, others seek to maintain their culture and local autonomy, while a minority of them have adopted elements of Han Chinese culture. ${ }^{3}$ Since 2016, the effort to eliminate Uyghur culture has been led by Xinjiang Communist Party Secretary Chen Quanguo, who previously adopted similar oppressive strategies in Tibet. ${ }^{4}$ On March 8, 2021, the Newlines Institute published a report which applied the 1948 Genocide Convention to the Uyghur situation in Xinjiang. It concluded that China was in violation of the convention for its intent to destroy the Uyghur group through violent acts against persons and the attempt to eradicate an identity and way of life, notably the Islamic traditions which Uyghur Muslims follow. ${ }^{5}$

The Chinese government has employed several tactics to root out any sign of resistance, and Islamic culture by extension, in Xinjiang. Utilizing facial recognition technology, comprehensive surveillance systems throughout the region track details about individuals' ways of life, including whether a person prays, visits mosques, fasts, or engages in other Islamic religion practices. ${ }^{6}$ Through a program known as "Becoming Family", ethnic Han Chinese cadres visit Uyghur households for homestays for periods lasting five days every two months, recording their observations of religious practices and attempting to "rectify" issues. ${ }^{7}$ The limited number of Uyghurs permitted to perform the Hajj to Mecca are tracked via GPS through the Chinese Islamic Association, and those who are suspected of having dangerous foreign connections have been handed prison sentences of 10-15 years. " "De-extremification" regulations passed in 2017 criminalize several other Islamic customs from having an "irregular" 
beard to the use of certain names. ${ }^{9}$ All information collected on the Uyghurs through these vast surveillance networks is stored in the Integrated Joint Operations Platform, which then flags certain individuals for investigation and detention. ${ }^{10}$

Current estimates suggest that between one to two million Uyghurs are held in detention facilities, which number between 1,300 and 1,400, excluding prisons. ${ }^{11}$ Detainees are closely watched and punished for any signs of religious observance, including praying. ${ }^{12}$ In addition to being shown Chinese Communist Party $(\mathrm{CCP})$ propaganda and forced to learn and speak Mandarin, they are sometimes forced to burn prayer mats on fire and eat pork. ${ }^{13}$ Washing one's hands or feet is often now allowed, and women in detention must apologize for wearing traditional Muslim clothing or having taught the Quran to their children. ${ }^{14}$ Nevertheless, the CCP still refers to the centers as "Vocational Skills Education Training Centers". ${ }^{15}$ The Chinese government also employs birth control measures, notably forced sterilizations of Uyghur women, which often conflict with Islamic tradition. ${ }^{16}$ In addition, rape and sexual abuse are widespread.

Starting in 2016, a Chinese government initiative known as "Mosque Rectification" has also led to the complete demolition of about 8,500 mosques. ${ }^{17}$ Mosques still standing have had their crescents atop them removed, or copies of the government's religious practice restrictions placed on their walls. ${ }^{18}$ Many mosques also remain locked, or checkpoints at the entrances discourage their usage. Through a separate program known as "Beautifying Spaces", Uyghur household architecture has been destroyed, including an arch facing Mecca for praying known as the mihrab. ${ }^{19}$ 
Public life has been largely cleansed of Islamic traditions as well. Halal labels are severely restricted, there are bans on wearing veils in public, and there are strict limitations on even the domestic movement of Uyghurs. ${ }^{20}$ Uyghur restaurants are not allowed to close during Ramadan, or the owners risk losing their license and detention. ${ }^{21}$ Imams are forced to register with the CCP, hundreds of Uyghur public figures have been detained, and they are often forced to renounce their religious beliefs publicly and pledge support to the CCP. ${ }^{22}$

\section{Civil Society Activism in the Islamic World}

The largest Uyghur diaspora community is located in Turkey, and it currently numbers approximately 50,000 refugees. ${ }^{23}$ As Southeast Asia is a common route for Uyghurs to flee from China for Turkey, Malaysia is also home to a Uyghur diaspora community and civil society activism. ${ }^{24}$ Many Uyghur migrants flee to Southeast Asia before intending to fly to Turkey, though some may stay in the region indefinitely. ${ }^{25}$ Uyghur activists are also present in Kazakhstan and Kyrgyzstan, not only because these are nations with large Turkic Muslim populations that border Xinjiang, but also because there are significant numbers of native Kazakhs and Kyrgyz in Xinjiang who are experiencing a similar crackdown to the Uyghurs. ${ }^{26}$ However, due to strong border control and security measures, crossing into Kazakhstan and Kyrgyzstan directly from Xinjiang is now quite rare for Uyghurs. ${ }^{27}$

Throughout these Islamic countries in close proximity to China or that share Turkic roots with the Uyghur people, civil society activism in support of the Uyghur cause has been relatively strong. During the 2019 presidential campaign in Indonesia, the opposition staged protests at Chinese consulates within the country to express solidarity with the Uyghur cause. ${ }^{28}$ At this time, 
reports suggested that about 36 percent of Indonesians had favorable views of China. However, while negative perceptions of China may increase the willingness of Indonesians to publicly express support for Uyghurs, they are not necessarily a direct result of Uyghur oppression. Similar protests have taken place in Malaysia as well, including a large, organized gathering on December 27, 2019, in Kuala Lumpur. ${ }^{29}$ The protest included multiple Muslim groups, including the more moderate and progressive Malaysian Muslim Youth Movement (Abim) along with the more fundamentalist, pan-Islamist group Hizbut Tahrir Malaysia (HTM) which is banned across much of the Muslim world. ${ }^{30}$ The spokesman for HTM, Abdul Hakim Othman, urged Malaysia to grant protection to fleeing Uyghur refugees, suspend diplomatic and economic ties with China, and be prepared to declare 'jihad'-meaning holy struggle. ${ }^{31}$ Throughout early 2021 , similar protests also occurred multiple times weekly outside the Chinese consulate in the city of Almaty, the capital of Kazakhstan. ${ }^{32}$ The protestors - many of whom were ethnic Kazakhsdemanded the release of their relatives being held in detention in China, also seeking an end to the genocide. ${ }^{33}$ In March 2020, one businessman in Turkey organized a boycott of Chinese products which was supported by many local companies. ${ }^{34}$ The Chinese consulate in Istanbul also witnessed several protests, mostly by individuals seeking information about family members who had gone missing, though these protests were banned in January 2021 over COVID-19 and security concerns. ${ }^{35}$

In many instances, civil society activism in the Islamic world has contributed to government measures in support of the Uyghur people, though these measures are usually limited in scope. In Turkey, the Industry Minister urged others to support the boycott of Chinese goods due to the violence against Uyghurs, but this did not become an official government 
policy. ${ }^{36}$ Following the 2019 protests, the Malaysian government refused to deport Uyghur asylum seekers back to China. ${ }^{37}$ In 2020, non-extradition of Uyghurs became the official policy of the Malaysian government, even if deportations were requested by Beijing. ${ }^{38}$ Furthermore, the Malaysian government announced a partnership with the International Institute of Islamic Thought and Civilization to generate a report on the Uyghur crisis in Xinjiang. ${ }^{39}$ In March 2021, the Foreign Ministry of Kazakhstan requested that China "help resolve issues" related to the relatives of protesters who are in custody in Xinjiang. ${ }^{40}$ This statement implicitly recognizes the unjust detentions despite taking a weaker position and simultaneously criticizing the protests for not following proper coronavirus protocols. While Kazakhstan is generally hesitant to create conflict with China, it has recently refrained from sending back to China ethnic Kazakhs who escaped from Xinjiang, instead granting them temporary asylum. ${ }^{41}$

Despite sufficient opportunities for criticisms and condemnations of Chinese policy in Xinjiang to be issued by governments, many of these statements issued by government officials and informal policies of non-extradition exist in the absence of official government condemnations. In July 2019, twenty-two nations signed onto a letter issued by the United Nations Human Rights Council which noted "disturbing reports of large-scale arbitrary detentions of Uighurs" and called on China to end such practices. ${ }^{42}$ Kazakhstan, Kyrgyzstan, Malaysia and Turkey all refrained from signing the letter, as did every Arab nation. However, the former four nations also refrained from signing a pro-China letter issued the same month, which recognized "terrorism, separatism and religious extremism" in Xinjiang and compared China's measures to "counter-terrorism and deradicalization". ${ }^{43}$ Meanwhile, several Arab nations signed the letter in support of China, including all members of the Gulf Cooperation Council except for 
Qatar, which signed but later withdrew. ${ }^{44}$ Similar statements were issued by the competing proand anti-China camps in October 2020, but their country makeups remained largely the same, and none of the aforementioned governments officially changed their stance. ${ }^{45}$ A 2019 document was also issued by the Organization of Islamic Cooperation (OIC) which "commends the efforts of the People's Republic of China in providing care to its Muslim citizens”, entirely ignoring abuses against Uyghurs. ${ }^{46}$ Nevertheless, the lack of an official, pro-Uyghur stance didn't completely prevent nations experiencing protests in support of the Uyghur cause to adopt supportive policies in response.

\section{Lack of Response in the Middle East}

While there has been strong civil society activism in support of the Uyghurs across parts of Southeast and Central Asia, activism has been relatively weaker in the Middle East. An open letter was written by the organizations Free Uyghur Now, US Council of Muslim Organizations and Save Uighur by Justice for All to the OIC in response to its implicit support of China's practices in 2019, and the letter had 140 organizations listed as signatories, including many Western student groups and 22 international Muslim organizations. ${ }^{47}$ Of those, nine were from Malaysia, four were from Turkey, one was from Kazakhstan, and only one was from the entirety of the Middle East: The Global Imams Council (GIC), based in Iraq. The letter declared, "We are appalled by OIC's commendation of China on its treatment of Muslims", adding that the Chinese

government "criminalises basic tenets of Islam practiced by Uyghurs and other Turkic groups", ${ }^{48}$ For its part, the GIC, a non-governmental body of over 1,000 Muslim religious leaders worldwide, also issued a separate statement in October 2020 in which its members "strongly condemn the systematic persecution of religious and ethnic people by the Chinese government" 
and recognizes the "torture, forced sterilization, kidnapping, forced brainwashing among other inhumane practices" faced by the Uyghurs. ${ }^{49}$ Despite the GIC statements, there have been practically no showings of solidarity with the Uyghurs from Middle Eastern governments or Arab supranational organizations.

Overall, despite some initial demonstrates of solidarity with the Uyghurs, Middle Eastern civil society groups and international Muslim organizations have generally been hesitant to get involved in the debate over Xinjiang. In 2009, in Xinjiang's regional capital of Ürümqi, Uyghur protests turned into riots with security forces getting involved. Ultimately, over 1,000 Uyghurs were detained or disappeared, and restrictions were placed on Uyghur movement and culture. ${ }^{50}$ While the World Muslim League, an international organization largely controlled by Saudi Arabia, demanded at a conference in 2010 that China give more religious freedom to Muslims in Xinjiang and protect their religious freedom, few follow up actions have occurred. ${ }^{51}$ In 2009, the International Union of Muslim Scholars took a stronger stance, condemning the actions by the Chinese government and calling on all governments in the Muslim world to pressure the Chinese government into protecting the religious freedom of the Uyghurs as well. ${ }^{52}$ However, although the Qatari-based organization includes many prominent religious leaders from throughout the Arab world, it has strong ties to the Muslim Brotherhood. Throughout much of the Middle East, the Muslim Brotherhood is outlawed and labeled as a group that sponsors terrorism despite historically using peaceful and democratic methods to create change. While prominent organizations such as the Organization of Islamic Cooperation, which includes many Arab nations, and the Arab League have been asked to support the Uyghur cause, they have not taken any public actions. ${ }^{53}$ 
On the contrary, governments throughout the Arab world have expressed support for the policies of China in Xinjiang. There have been occasional instances where politicians in the Arab world have called for actions to project the Uyghurs, including in 2009 when forty Jordanian parliamentarians called for the government to condemn China's oppressive actions. However, this did not lead to any formal government actions. ${ }^{54}$ Most member nations of the Arab League have instead backed UN letters in support of China's policies, but with some notable exceptions, including Jordan, Lebanon, Qatar and Tunisia. ${ }^{55}$ Furthermore, many governments across the Middle East have cooperated with Chinese authorities for investigations or extradition requests. Following a 2017 meeting between Egyptian and Chinese officials, at least twelve Uyghurs who had been studying at Al-Azhar University in Egypt were deported back to China, and many more were detained by Egyptian authorities. ${ }^{56}$ A report by BBC Newsnight also uncovered cases of exiled Uyghurs being targeted in the United Arab Emirates, Saudi Arabia, and Egypt. ${ }^{57}$

The lack of an official response from Arab governments in support of the Uyghurs stems from multiple factors, including the growing economic reliance of many Middle Eastern governments on Beijing. Eighteen Arab countries have signed cooperation agreements with China's Belt and Road Initiative (BRI). Furthermore, four Middle Eastern nations have signed comprehensive strategic partnerships with China, which represents the highest level of participation and cooperation in the BRI: the United Arab Emirates, Saudi Arabia, Egypt and Iran. ${ }^{58}$ Chinese investments are responsible for creating numerous significant infrastructure projects across the region, including a rail system in Tehran and the Haramain railway, which runs from Mecca to Medina. ${ }^{59}$ Chinese businesses also have contracts totaling at least $\$ 35.6$ 
billion in the Arab world on top of annual trade exceeding $\$ 200$ billion. ${ }^{60}$ In 2018 , Saudi Arabia alone accounted for $\$ 46$ billion in imports from China, and Saudi Arabia relies on Chinese oil demand as well. ${ }^{61}$ On a 2019 visit to Beijing, Saudi crown prince Mohammad bin Salman publicly spoke in favor of China's policies in the Xinjiang region. ${ }^{62}$ With Chinese investment in Pakistan totaling over $\$ 62$ billion, much of which is designated for the development of the city of Islamabad, Pakistan Prime Minister Imran Khan also expressed praise for the Chinese government and would not address the situation in Xinjiang. ${ }^{63}$ Recently, Pakistani authorities have begun to collect biometric data on Uyghurs residing in Pakistan and deport many back to China. ${ }^{64}$

Another cause of the lack of response from Arab governments is the threat of militant groups of Uyghur extremists within the Middle East, against whom Middle Eastern countries have cooperated with Chinese intelligence. The Turkistan Islamic Party (TIP) is often seen as the main Uyghur extremist group, and it calls for the establishment of an independent state of East Turkestan in present-day Xinjiang. While it has, in some instances, been designated as a "terrorist" organization, the United States removed the TIP from its list of terrorist organizations in November 2020. According to a US State Department official, there was "no credible evidence" that the TIP still exists in an organized capacity. Rather, the TIP today resembles a disorganized group of Uyghur militant fighters within the Middle East.

In 2017, in the middle of the Syrian Civil War, the Syrian ambassador to China reported upwards of 5,000 Uyghurs fighting alongside militant groups, and Syrian President Bashar alAssad commended the cooperation between Syrian and Chinese intelligence against Uyghur 
forces. ${ }^{65}$ While coalition forces largely defeated ISIS in Syria in 2017, TIP militants continued to fight as a part of Hayat Tahrir al-Sham with numbers from 1,000 to $5,000 .{ }^{66}$ However, many Uyghur militants choose to continue fighting in Syria mainly because of a lack of a clear alternative. In Turkey, Uyghurs often face substantial language barriers, discrimination and poor employment outlooks. ${ }^{67}$

Notably, while TIP militants currently operate in Afghanistan, Pakistan, Syria and Iraq, they largely lack sufficient numbers to carry out their own operations beyond the Middle East. ${ }^{68}$ The TIP has not demonstrated the organization and capacity to conduct operations within China. While it claims responsibility for an attack on the Urumqi open-air market in 2014, its connection to the attack is inconclusive, and there have been no terrorist incidents connected to the TIP within China since then. ${ }^{69}$ Nevertheless, terrorist attacks in China which are not necessarily connected to the TIP have drawn attention and criticism from Middle Eastern governments. In 2014, after Uyghurs were blamed for a large-scale knife attack in Kunming, China, which left dozens killed, the attack was condemned by several Arab nations as well as the Arab League collectively. ${ }^{70}$

Both the Uyghur population in China and Uyghur refugee populations abroad are seen by Arab governments as recruitment opportunities for Uyghur militant groups operating in the Middle East such as the TIP. ${ }^{71}$ A major cause of the relationship between jihadist groups and Uyghur exiles is the successful tactics which extremist groups have used to recruit Uyghurs in the absence of safe alternatives in exile. Many Uyghur asylum seekers have become connected to militant groups in Southeast Asia after failing to travel from Southeast Asia to Turkey, where 
there is a larger Uyghur diaspora. ${ }^{72}$ As far back as 2014, four Uyghurs were arrested in Indonesia for attempting to join the extremist organization Mujahidin Indonesia Timur. ${ }^{73}$ China's treatment of Uyghurs is also frequently criticized by leaders of Al-Qaeda and other extremist groups. ${ }^{74}$ ISIS, Al-Qaeda, and their affiliates in Southeast Asia have attempted to use the region as a recruiting point for Uyghurs to improve their operations in the Middle East, including by encouraging Uyghurs trapped in Southeast Asia to fight in the Middle East to oppose the global interests of China. $^{75}$

The Chinese government has also taken great measures aimed at maintaining support across the Middle East, both among governments and local populations. In fighting terrorism and extremism, China positions itself as an asset to Middle Eastern governments. There is a Chinese military base in Djibouti, and in December 2019, China conducted a joint naval exercise with Russia and Iran in the Gulf of Oman. ${ }^{76}$ Cultural exchange is also a strategy which China uses to promote its interests and reputation in the region. Throughout the Middle East, there are twentythree Confucius Institutes through which China promotes cultural exchange and projects soft power. ${ }^{77}$ The Chinese Islamic Association also works to defend the reputation of China in the Middle East through connecting Chinese Muslims with the greater Muslim world in a controlled and surveilled manner. It frequently does this through hosting world and religious leaders from the Islamic world, including giving a tour to King Salman of Saudi Arabia in 2014 of Chinese mosques. This was followed by a donation of $\$ 3$ million by King Salman to develop Islamic cultural centers in China. ${ }^{78}$ The Association also maintains an exchange program with al-Azhar University in Egypt, and it praises the university for taking measures to combat extremism in the Middle East. ${ }^{79}$ 
China has also published multiple statements in the Arab media to defend its treatment of Uyghurs in the Xinjiang region. In November 2020, Guo Wei, the Chinese Ambassador to Palestine, published a statement translated into Arabic in Ma'an News, an independent Palestinian news agency, in which he praised the stability, economic development and prosperity of Xinjiang. ${ }^{80}$ Similarly, through the Algerian press agency Echorouk News, the Chinese Ambassador to Algeria Li Lianhe published a statement in January 2021 which praised freedom of religion in Xinjiang and criticized the Western media for "spreading a lot of fake news with the aim of misleading international public opinion and stirring discord". ${ }^{81}$ The Chinese state media also broadcasts messages to promote its narrative around Xinjiang, primarily through Arabic language articles in state-owned papers such as CGTN and People's Daily. A CGTN article from January 2021 was published under the headline, "The Chinese Government is committed to protecting the religious freedom of Muslims". ${ }^{82}$ A February 2021 article in the People's Daily addressed criticisms of its 'vocational centers' by stating in its headline, "It's a campus, not a camp". 83

\section{Arab Populations, the Media, and Xinjiang}

Despite the pressure from China and lack of official government support for the Uyghur cause across the Middle East, Arab populations generally sympathize with the Uyghurs. A September 2020 poll by the Palestinian Center for Policy and Survey Research inquired about the perception of Palestinians towards Muslims in China, and the results showed overwhelming support for the Uyghur cause. 83 percent of respondents believed that Palestinians should show 
solidarity against the Chinese government. Furthermore, 79 percent do not believe the Chinese government that the detention centers are educational centers intending to eliminate extremism, compared to 10 percent who do believe the Chinese statements. ${ }^{84}$ Organizations such as the Uyghur Human Rights Project (UHRP) and World Uyghur Congress have been receiving more requests to get involved from across the Muslim world, including the Arab world, as a result of shifting public opinion. ${ }^{85}$

Recently, the media throughout the Arab world is showing a greater degree of solidarity with the Uyghurs in China. Ultimately, this coverage can shift public opinion further, even without full-fledged support for the Uyghur cause. Since many newspapers across the Arab world are state-owned or operating in environments where there are limitations to free press, there have been relatively few articles published in the Arab media about the Uyghur crisis over the course of the past decade. However, recent reports with detailed evidence of the happenings in Xinjiang and Western governments' labels of genocide in Xinjiang have led to increased media coverage in the Middle East. While the coverage tends to focus more on detailing the reports and statements made in the Western world rather than providing new opinions, the articles suggest a degree of sympathy and solidarity with the Uyghurs as a Muslim population.

Al-Quds, a popular Palestinian newspaper based in Jerusalem, has published several articles in late-2020 and early-2021 about the Uyghur crisis, including articles about the Canadian recognition of the events in Xinjiang as a genocide, the draft resolution in Belgium with a similar declaration, and the surveillance operations conducted by Chinese authorities in the region. Al-Quds frequently refers to the region as 'East Turkestan' instead of Xinjiang, the 
former being the historical name of the region which is preferred by Uyghurs seeking independence and throughout most of the Turkic world. East Turkestan is the label consistently given to the region by many Turkish publications, including Daily Sabah, Anadolu Agency, and Zaman.

Al-Jazeera, a popular international Arabic news source based in Qatar, has published several recent articles about the developments in Xinjiang, particularly by reporting on Western treatment of the crisis. One article written by Al-Jazeera in December 2020 focused on then U.S. National Security Advisor Robert O'Brien's label of the crisis as a genocide, referring to the region as East Turkestan in addition to Xinjiang and describing some of the abuses, including "infertility, forced abortion and forcible family planning" ${ }^{86}$

Many Arabic-language articles examining the situation in Xinjiang call out the Turkish government's abandonment of Uyghur Muslims, but in addition to criticizing Turkey, these articles still spread awareness of Chinese abuses in the region. Criticisms of the Turkish government arise not only from ethnic tensions between Turkic and Arab populations, but also from fears that Turkey will ratify a proposed extradition deal with China. The deal would give China a legal avenue to request that Uyghurs living abroad in Turkey be extradited back to China. While the extradition bill was proposed in 2017, it had not been ratified by either country until December 2020 when China officially ratified the deal. The ratification aligned with the arrival of millions of Sinovac vaccines in Turkey from China, sparking suspicions that Turkey would bend to Chinese demands in Xinjiang to secure more vaccines and stronger economic support from China. ${ }^{87}$ Masrawy, an Egyptian Arabic news organization, published an article 
detailing some of the abuses in Xinjiang and the cooperation of Turkey under the headline, "False Hope... Why did Erdogan abandon the Uyghur Muslims?" which accused the Turkish authorities of cooperating with deportation requests from Beijing. ${ }^{88}$ Another article published in Al-Arab, a pan-Arab paper from London, outlined the fears of Uyghurs living in Turkey over the extradition deal and was titled, "Is Turkey colluding with China Against the Uyghur Muslims?". ${ }^{89}$ Asharq Al-Awsat, another Arabic-language paper based in London, published multiple articles in March 2021 about the extradition deal, including an interview with a Uyghur currently living in Turkey who had spent twenty years imprisoned in China. ${ }^{90}$

Several other Arabic-language sources have published anecdotal stories about abuses in Xinjiang as opposed to summarizing reports or statements made in the West. Al-Watan, a Saudi paper which is generally considered to be among the more liberal papers in the country, published a story in February 2021 headlined “"They Boast of Rape Stories'... Horrifying Testimony from Inside Uyghur Camps". The article described an interview with a teacher who witnessed widespread sexual abuse of women by Chinese authorities while at a forced labor camp. The teacher described the events as "so disturbing' that it made her ill”. ${ }^{91}$ Similarly, AlAan, a Dubai-based pan-Arab source, wrote a March 2021 article containing anecdotes from Uyghurs who had been sentenced in China, including a doctor given 20 years for terrorism and a student sentenced to 9 years for receiving an education abroad. ${ }^{92}$ 


\section{Recommendations}

As media coverage creates awareness and discussions about the Uyghur crisis across the Arab world and polls suggest growing pro-Uyghur sentiments, opportunities are expanding for civil society to organize and show greater solidarity and support for the Uyghurs. Despite the economic ties shared by countries in Southeast and Central Asia with China and the intimidation and threats which China can use, countries such as Kyrgyzstan, Kazakhstan and Malaysia have been able to carefully navigate the situation to respond to civil society activism while not exacerbating conflicts with China. While Middle Eastern governments are unlikely to take actions individually which directly condemn China's treatment of the Uyghur Muslims, enough pressure may cause them to support statements drafted by regional and international organizations, such as the Arab League, Organization of Islamic Cooperation and United Nations, which condemn China. Furthermore, as other nations in the Islamic world have done, pressure could cause Middle Eastern governments to refuse to cooperate with Chinese authorities on extradition requests. While Middle Eastern nations do not currently have a Uyghur diaspora as large as that in Turkey, establishing the region as a safe haven could encourage more Uyghur students to attend university in the Middle East, or seek permanent asylum along with their families. If persecuted Uyghurs are given a chance to receive an education and establish legal residence across the region, the recruiting opportunities for terrorist networks in the Middle East and Southeast Asia would likewise decrease. Given the greater security this may create for Middle Eastern governments, evidence of growing support for the Uyghur cause and civil society activism across the Middle East may be the final necessary components for governments in the region to express their solidarity. 
Numerous global and regional stakeholders can play an important role in mobilizing civil society towards creating greater protection for Uyghurs across the Middle East. International organizations such as the World Uyghur Congress and UHRP, along with human-rights oriented NGOs, can provide support for regional civil society groups through capacity building efforts and using their established social media followings to amplify work being done on the ground. Social media campaigns can be an effective way to promote more discussion and awareness of the Uyghur genocide across the region, enlarging grassroots activism efforts. Established local groups should utilize discussions, petitions, and protests to encourage government action. Despite restrictions that may be in place on association and assembly in certain Middle Eastern countries, specifically protesting actions by the Chinese government outside Chinese embassies has been an effective tool in Central Asia and Southeast Asia that could draw media attention and indirectly spark government action.

The press also has a role to play in encouraging civil society activism by continuing to spread awareness of the events in Xinjiang. In addition to independent publications, even state owned papers have begun to report on the crisis, particularly by reporting on Western reactions and sharing details about the ongoing genocide. While there are limitations to how critical stateowned publications across the region are of Chinese policy, pan-Arab publications published in the Western world and read across the region should take advantage of their greater freedom over content to provide more detailed and frequent descriptions of abuses in Xinjiang. Local press, however, would have to perform a greater share of the reporting on civil society activism and protests, especially if protests occur on a small scale. 
The intellectual community also has an important role to play in creating solidarity with the Uyghur cause across the Middle East. Universities across the United States have seen groups of college students mobilize to spread awareness alongside organizations such as the World Uyghur Congress, and universities across the Middle East would similarly be suitable spaces to encourage dialogue and activism. In particular, universities across the region with Uyghur students would be productive spaces to build solidarity between local students and Uyghurs. Uyghur students may be more willing to express their beliefs and experiences, however, after Middle Eastern governments adopt policies of non-extradition. Scholars also play an important role in building support and solidarity, especially Muslim religious scholars and leaders. Not only can they take on leadership roles in encouraging student and civil society activism, but they can leverage their positions as leaders of the Muslim community to encourage religious solidarity that bridges ethnic divides.

Finally, research groups should conduct similar surveys to the survey conducted by the Palestinian Center for Policy and Survey Research which revealed strong support among Palestinians for the Uyghur cause. These surveys help inform civil society leaders where grassroots efforts may be most effective, and they may also be an important tool for informing Middle Eastern governments about shifting public opinion as they consider taking future action. 
Notes

${ }^{1}$ Christie Wan, "The Persecution of the Uyghurs and Potential International Crimes in China," August 2020, https://www.justsecurity.org/wp-content/uploads/2020/08/XinjiangReport-Version-5.0-Aug.-2020.pdf, 4.

2 Yonah Diamond et al., “The Uyghur Genocide: An Examination of China's Breaches of the 1948 Genocide Convention" (Newlines Institute for Strategy and Policy, March 2021), https://newlinesinstitute.org/wp-content/uploads/Chinas-Breaches-of-the-GC3.pdf, 18.

${ }^{3}$ Hanan Kamal Sekin, "Arab States and The Unrest in China's Xinjiang Province," World Affairs: The Journal of International Issues 19, no. 3 (2015): pp. 118-133, https://www.jstor.org/stable/48505459, 131.

${ }^{4}$ Wan, "Persecution of the Uyghurs", 8.

${ }^{5}$ Diamond et al., "Uyghur Genocide", 9.

${ }^{6}$ Ibid, 18-21.

${ }^{7}$ Ibid.

${ }^{8}$ Ali Çaksu, "Islamophobia, Chinese Style: Total Internment of Uyghur Muslims by the People's Republic of China," Islamophobia Studies Journal 5, no. 2 (2020): pp. 175-198, https://www-jstor-org.ezp-prod1.hul.harvard.edu/stable/10.13169/islastudj.5.2.0175, 180.

${ }^{9}$ Ibid.

${ }^{10}$ Wan, "Persecution of the Uyghurs", 11-12.

${ }^{11}$ Diamond et al., "Uyghur Genocide”, 23.

${ }^{12}$ Wan, "Persecution of the Uyghurs", 54-55.

${ }^{13}$ Diamond et al., "Uyghur Genocide”, 29.

${ }^{14}$ Çaksu, "Islamophobia, Chinese Style", 180.

15 Wan, "Persecution of the Uyghurs", 14.

${ }^{16}$ Diamond et al., "Uyghur Genocide", 31-33.

${ }^{17}$ Ibid, 43.

18 Wan, "Persecution of the Uyghurs", 23. 
${ }^{19}$ Diamond et al., "Uyghur Genocide", 44.

${ }^{20}$ Wan, "Persecution of the Uyghurs", 21.

${ }^{21}$ Çaksu, "Islamophobia, Chinese Style", 184.

22 Wan, "Persecution of the Uyghurs", 21.

${ }^{23}$ Dorian Jones, “Turkish Opposition Challenge Erdogan Over Uighur Silence," Voice of America, January 28, 2021, https://www.voanews.com/europe/turkish-opposition-challengeerdogan-over-uighur-silence.

${ }^{24}$ Umair Jamal, “Quiet Defiance: Understanding Malaysia's Careful Stance on Uyghur Muslims," ASEAN Today, December 20, 2020, https://www.aseantoday.com/2020/12/quietdefiance-understanding-malaysias-careful-stance-on-uyghur-muslims/.

${ }^{25}$ Nodirbek Soliev, "Uyghur Violence and Jihadism in China and Beyond," Counter Terrorist Trends and Analyses 11, no. 1 (2019): pp. 71-75, https://www.jstor.org/stable/26568580, 75.

${ }^{26}$ Bruce Pannier, "Why Are Central Asian Countries Silent About China's Uyghurs?," RadioFreeEurope/RadioLiberty, September 23, 2020, https://www.rferl.org/a/why-are-centralasian-countries-silent-about-china-s-uyghurs-/30852452.html.

27 Soliev, "Uyghur Violence", 75.

${ }^{28}$ Nithin Coca, "The Long Shadow of Xinjiang," Foreign Affairs, September 10, 2020, https://www.foreignaffairs.com/articles/china/2020-09-10/long-shadow-xinjiang.

${ }^{29}$ Soo Wern Jun, Azril Annuar, and Jerry Choong, "In KL, Hundreds of Muslims Protest against China's Treatment of Uighurs: Malay Mail," Malaysia | Malay Mail (Malay Mail, December 27, 2019), https://www.malaymail.com/news/malaysia/2019/12/27/in-kl-hundreds-ofmuslims-protest-against-chinas-treatment-of-uighurs/1822584.

${ }^{30}$ Ibid.

31 Ibid.

${ }^{32}$ Chris Rickleton, "After Tentative Start, Kazakhstan Is Obliterating Xinjiang Activism," Eurasianet, February 22, 2021, https://eurasianet.org/after-tentative-start-kazakhstanis-obliterating-xinjiang-activism.

33 "Kazakhs Continue Picket Of Chinese Consulate For Release Of Xinjiang Relatives," RadioFreeEurope/RadioLiberty, February 22, 2021, https://www.rferl.org/a/kazakhs-continuepicket-of-chinese-consulate-for-release-of-xinjiang-relatives/31115377.html. 
${ }^{34}$ Coca, "Long Shadow of Xinjiang".

${ }^{35}$ Asim Kashgarian and Ezel Sahinkaya, "Turkey Cracks Down on Uighur Protesters After China Complains," Voice of America, March 5, 2021, https://www.voanews.com/eastasia-pacific/turkey-cracks-down-uighur-protesters-after-china-complains.

${ }^{36}$ Yitzhak Shichor, "See No Evil, Hear No Evil, Speak No Evil: Middle Eastern Reactions to Rising China's Uyghur Crackdown," Griffith Asia Quarterly 3, no. 1 (2015), https://docs.uyghuramerican.org/pdf/629-2058-1-PB.pdf, 68.

${ }^{37}$ Coca, "Long Shadow of Xinjiang".

${ }^{38}$ Umair Jamal, “Quiet Defiance: Understanding Malaysia's Careful Stance on Uyghur Muslims," ASEAN Today, December 20, 2020, https://www.aseantoday.com/2020/12/quietdefiance-understanding-malaysias-careful-stance-on-uyghur-muslims/.

${ }^{39}$ Ibid.

40 "Nur-Sultan Wants China 'To Help Resolve Issues' Raised By Ethnic Kazakhs From Xinjiang," RadioFreeEurope/RadioLiberty, March 15, 2021, https://www.rferl.org/a/kazakhschina-consulate-protesters-relatives-xinjiang-release/31147667.html.

${ }^{41}$ Rickleton, “After Tentative Start”.

42 “United Nations Digital Library,” United Nations Digital Library, July 23, 2019, https://undocs.org/A/HRC/41/G/11.

43 “United Nations Digital Library,” United Nations Digital Library, August 9, 2019, https://digitallibrary.un.org/record/3853509? $1 \mathrm{n}=\mathrm{en}$.

${ }^{44}$ Haisam Hassanein, “Arab States Give China a Pass on Uyghur Crackdown,” The Washington Institute for Near East Policy, 2019, https://www.washingtoninstitute.org/policyanalysis/arab-states-give-china-pass-uyghur-crackdown.

45 "General Debate," in Third Committee Summary Record of the 3rd Meeting (New York City, 2020), https://undocs.org/en/A/C.3/75/SR.3, 3-4.

46 "Resolution No.1/46-MM on Safeguarding the Rights of Muslim Communities and Minorities in Non-OIC Member States," in RESOLUTIONS ON MUSLIM COMMUNITIES AND MUSLIM MINORITIES IN THE NON-OIC MEMBER STATES (Abu Dhabi:

Organization of Islamic Cooperation, 2019), https://www.oicoci.org/docdown/?docID=4447\&amp;refID=1250, 5 .

${ }^{47}$ Save Uighur by Justice for All, Free Uyghur Now, and US Council on Muslim Organizations, "Justice for All," Justice for All, December 17, 2020, 
https://2vwenc1h9jiauuq402mipy51-wpengine.netdna-ssl.com/wpcontent/uploads/2020/12/Open-Letter-to-OIC.pdf.

${ }^{48}$ Ibid.

49 "Global Imams Council," Global Imams Council, October 1, 2020, https://imams.org/statements/.

${ }^{50}$ Diamond et al., "Uyghur Genocide", 16.

51 "Justice for All".

${ }^{52}$ Sekin, “Arab States”, 127-130.

${ }^{53}$ Ibid, 124-126.

${ }^{54}$ Shichor, "See No Evil".

${ }^{55}$ Third Committee Summary Record, "General Debate", 3-4.

56 "Middle East Countries Deported Exiled Uighurs to China: Report," Middle East Eye, February 2020, https://www.middleeasteye.net/news/uighur-china-middle-east-deport-beijing.

57 "Middle East Countries Deported Exiled Uighurs".

${ }^{58}$ Erzsébet N. Rózsa, "Deciphering China in the Middle East" (European Union Institute for Security Studies (EUISS), 2020), http://www.jstor.org/stable/resrep25023, 4.

${ }^{59}$ Ibid, 6.

${ }^{60}$ Hassanein, "Arab States Give China”.

61 "Middle East Countries Deported Exiled Uighurs".

62 Jilil Kashgary, "Four Uyghurs Facing Persecution After Deportation by Saudi Arabia to China Identified," trans. Joshua Lipes, Radio Free Asia, November 21, 2020, https://www.rfa.org/english/news/uyghur/deportation-10162020150910.html.

${ }^{63}$ Aykan Erdemir and Philip Kowalski, "China Buys Turkey's Silence on Uyghur Oppression," The Diplomat, August 21, 2020, https://thediplomat.com/2020/08/china-buysturkeys-silence-on-uyghur-oppression/.

${ }^{64}$ Brent E Huffman, "Pakistan Is Cracking Down on Uyghur Muslims Who Fled China," VICE, May 21, 2021, https://www.vice.com/en/article/akgee4/pakistan-is-cracking-down-onuyghur-muslims-who-fled-china. 
65 Ben Blanchard, "Syria Says up to 5,000 Chinese Uighurs Fighting in Militant Groups," Reuters, May 11, 2017, https://www.reuters.com/article/uk-mideast-crisis-syria-china/syria-saysup-to-5000-chinese-uighurs-fighting-in-militant-groups-idUSKBN1840UP.

${ }^{66}$ Soliev, "Uyghur Violence", 73.

${ }^{67}$ Gerry Shih, “AP Exclusive: Uighurs Fighting in Syria Take Aim at China,” AP NEWS (Associated Press, December 22, 2017), https://apnews.com/article/syria-ap-top-news-riotsinternational-news-china-79d6a427b26f4eeab226571956dd256e.

${ }^{68}$ Nodirbek Soliev, "Uyghur Militancy in and beyond Southeast Asia," Counter Terrorist Trends and Analyses 9, no. 2 (2017): pp. 14-20, http://www.jstor.org/stable/26351495, 15.

${ }^{69}$ Soliev, "Uyghur Violence", 71.

${ }^{70}$ Sekin, “Arab States”, 124.

${ }^{71}$ Soliev, "Uyghur Violence", 75.

72 Ibid.

73 Soliev, "Uyghur Militancy", 14.

${ }^{74}$ Shichor, "See No Evil".

75 Soliev, "Uyghur Militancy", 15.

${ }^{76}$ Rózsa, “Deciphering China”, 6.

${ }^{77}$ Ibid.

${ }^{78}$ Lucille Greer and Bradley Jardine, "The Chinese Islamic Association in the Arab World: The Use of Islamic Soft Power in Promoting Silence on Xinjiang," Middle East Institute, July 14, 2020, https://www.mei.edu/publications/chinese-islamic-association-arab-world-useislamic-soft-power-promoting-silence.

${ }^{79}$ Ibid.

${ }^{80}$ Guo Wei, “صنع المستقبل الأكثر إشر اقا لشينجيانغ [Making a Brighter Future for Xinjiang]," وكالـة مسـا الاخبـارية, November 19, 2020, https://www.maannews.net/articles/2024461.html.

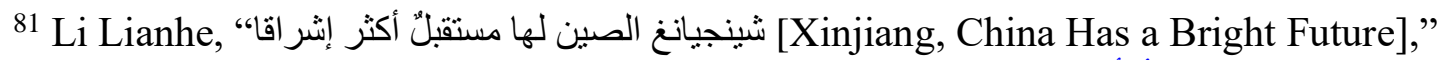

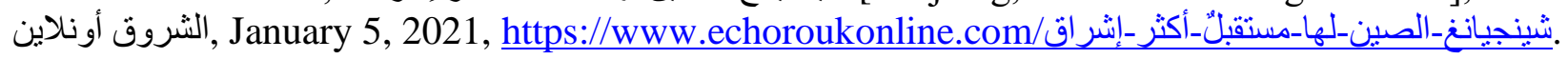

[President of رئيس الجمعية الإسلامية الصينية: الحكومة الصينية ملتزمة بحماية الحرية الدينية للمسلمين، 82 the Chinese Islamic Association: The Chinese Government Is Committed to Protecting the 
Religious Freedom of Muslims],” CGTN العربية , January 8, 2021, https://arabic.cgtn.com/n/BfJEA-EA-CAA/FBEAcA/index.html.

إنه حرمًا جامعيًا وليس ، :صحفي باكستاني يروي قصصًا عن حقيقة مر اكز التدريب المهني في شينجيانغ،، 83 [Pakistani Journalist Tells Stories about the Reality of Vocational Training Centers in Xinjiang: 'It's a Campus, Not a Camp],” People's Daily Online, February 26, 2021, http://arabic.people.com.cn/n3/2021/0226/c31664-9822636.html.

84 “ Public Opinion Poll No (77)" ( Palestinian Center for Policy and Survey Research, September 15, 2020), https://www.pcpsr.org/sites/default/files/Poll\%2077\%20English\%20press\%20release\%20Septem ber2020.pdf, 8 .

${ }^{85}$ Coca, "Long Shadow of Xinjiang".

[US Official: What Is

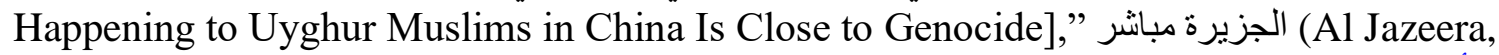

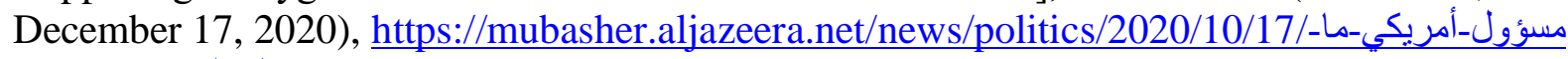
يحدث_لمسلمي-الإيغور-في

${ }^{87}$ Dorian Jones, “Turkish Opposition Challenge Erdogan Over Uighur Silence," Voice of America, January 28, 2021, https://www.voanews.com/europe/turkish-opposition-challengeerdogan-over-uighur-silence.

${ }^{88}$ Muhammad Safwat, “ب أمل زائف.. لماذا تخلى أردو غان عن مسلمي الإيجور [False Hope.. Why Did Erdogan Abandon the Uyghur Muslims]," مصراوي, March 3, 2021, https://www.masrawy.com/news/news_publicaffairs/details/2021/3/3/1980898/أمل-زائف_لماذا_تخلىي أردو غان-عن-مسلمي-الإيجور.

[Is Turkey Colluding with China against the

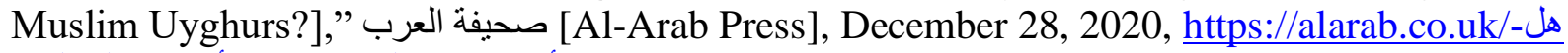

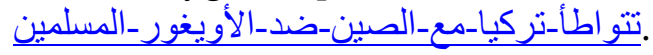

${ }^{90}$ Ibid.

['They Flaunt Stories of Rape'... A Shocking Testimony from inside the Uyghur Camps],” Al-Watan, February 19, 2021,

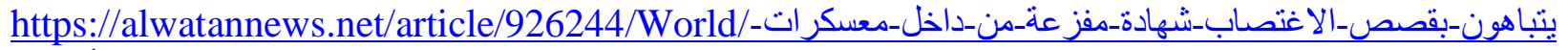
الأويغور

92 Ghaith Haddadin, "ضحايا الإيغور ..اضطهاد يطيل أمد معاناة هذه الأقلية] [Victims of the Uyghurs... persecution Prolongs the Suffering of This Minority]," أخبار الآن [News Now], March 7, 2021, https://www.akhbaralaan.net/news/world/2021/03/07/ضحايا_الإيغور -اضطهاد_يطيل_أمد_معاناة_هذه_الأقلية" 


\section{Bibliography}

"46th Session of the Council of Foreign Ministers." In Resolutions on Muslim Communities and Muslim Minorities in the non-OIC Member States. Abu Dhabi: Organization of Islamic Cooperation, 2019. https://www.oic-oci.org/docdown/?docID=4447\&refID=1250.

Abbas, Rushan. "International Action to Protect the Uyghur People." Journal of International Affairs 73, no. 2 (2020): 211-16. https://www.jstor.org/stable/26939976.

Abdel Hadi, Shaima. "الجمعية الإسلامية الصينية تثيد بدور الأزهر في تدريب الأئمة الصينيين] [Chinese Islamic Association Praises Al-Azhar's Role in Training Chinese Imams]."بورنة الأبة الأهرام, November 23, 2019. https://gate.ahram.org.eg/News/2285349.aspx.

Blanchard, Ben. "Syria Says up to 5,000 Chinese Uighurs Fighting in Militant Groups." Reuters, May 11, 2017. https://www.reuters.com/article/uk-mideast-crisis-syria-china/syria-says-upto-5000-chinese-uighurs-fighting-in-militant-groups-idUSKBN1840UP.

Bostock, Bill. "Turkey Is Accused of Extraditing Uighur Muslims to China in Exchange for COVID-19 Vaccines." Business Insider, January 16, 2021.

https://www.businessinsider.com/turkey-accused-of-extraditing-uighur-muslims-for-chinacoronavirus-vaccine-2021-1.

Coca, Nithin. "The Long Shadow of Xinjiang." Foreign Affairs, September 10, 2020. https://www.foreignaffairs.com/articles/china/2020-09-10/long-shadow-xinjiang.

Debata, Mahesh Ranjan, and Robert Guang Tian. "A Cultural Rights Approach vs. Nationalist Mobilization: an Applied Anthropological Case Study of the Uyghur Diaspora Community." Practicing Anthropology 33, no. 4 (2011): 35-38. http://www.jstor.org/stable/24782017.

Diamond, Yonah et al. Rep. The Uyghur Genocide: An Examination of China's Breaches of the 1948 Genocide Convention. Newlines Institute for Strategy and Policy, March 2021. https://newlinesinstitute.org/wp-content/uploads/Chinas-Breaches-of-the-GC3.pdf.

Erdemir, Aykan, and Philip Kowalski. "China Buys Turkey's Silence on Uyghur Oppression." The Diplomat, August 21, 2020. https://thediplomat.com/2020/08/china-buys-turkeyssilence-on-uyghur-oppression/.

Greer, Lucille, and Bradley Jardine. "The Chinese Islamic Association in the Arab World: The Use of Islamic Soft Power in Promoting Silence on Xinjiang." Middle East Institute, July 14, 2020. https://www.mei.edu/publications/chinese-islamic-association-arab-world-useislamic-soft-power-promoting-silence.

Haddadin, Ghaith. "ضحايا الإيغور..اضطهاد يطيل أمد معاناة هذه الأقلية [Victims of the Uyghurs...

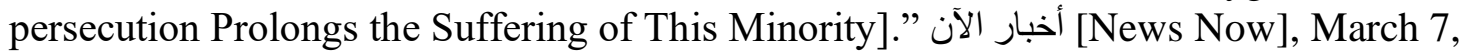




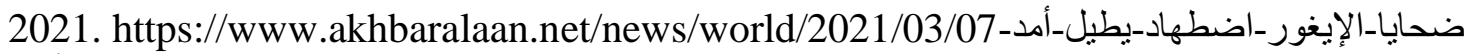
معاناة_هذه-الأقلية

Hassanein, Haisam. “Arab States Give China a Pass on Uyghur Crackdown.” The Washington Institute for Near East Policy, 2019. https://www.washingtoninstitute.org/policyanalysis/arab-states-give-china-pass-uyghur-crackdown.

Huffman, Brent E. "Pakistan Is Cracking Down on Uyghur Muslims Who Fled China." VICE, May 21, 2021. https://www.vice.com/en/article/akgee4/pakistan-is-cracking-down-onuyghur-muslims-who-fled-china.

Jamal, Umair. "Quiet Defiance: Understanding Malaysia's Careful Stance on Uyghur Muslims." ASEAN Today, December 20, 2020. https://www.aseantoday.com/2020/12/quiet-defianceunderstanding-malaysias-careful-stance-on-uyghur-muslims/.

Jones, Dorian. "Turkish Opposition Challenge Erdogan Over Uighur Silence.” Voice of America, January 28, 2021. https://www.voanews.com/europe/turkish-oppositionchallenge-erdogan-over-uighur-silence.

Kashgarian, Asim, and Ezel Sahinkaya. "Turkey Cracks Down on Uighur Protesters After China Complains.” Voice of America, March 5, 2021. https://www.voanews.com/east-asiapacific/turkey-cracks-down-uighur-protesters-after-china-complains.

Kashgary, Jilil. "Four Uyghurs Facing Persecution After Deportation by Saudi Arabia to China Identified." Translated by Joshua Lipes. Radio Free Asia, November 21, 2020. https://www.rfa.org/english/news/uyghur/deportation-10162020150910.html.

"Kazakhs Continue Picket of Chinese Consulate for Release of Xinjiang Relatives." RadioFreeEurope/RadioLiberty, February 22, 2021. https://www.rferl.org/a/kazakhscontinue-picket-of-chinese-consulate-for-release-of-xinjiang-relatives/31115377.html.

Letter to President of the Human Rights Council. "Letter Dated 12 July 2019 from the Representatives of Algeria, Angola, Bahrain, Bangladesh, Belarus, the Plurinational State of Bolivia, Burkina Faso, Burundi, Cambodia, Cameroon, Comoros, the Congo, Cuba, the Democratic People's Republic of Korea, the Democratic Republic of the Congo, Djibouti, Egypt, Equatorial Guinea, Eritrea, Gabon, the Islamic Republic of Iran, Iraq, Kuwait, the Lao People's Democratic Republic, Mozambique, Myanmar, Nepal, Nigeria, Oman, Pakistan, the Philippines, the Russian Federation, Saudi Arabia, Serbia, Somalia, South Sudan, Sri Lanka, the Sudan, the Syrian Arab Republic, Tajikistan, Togo, Turkmenistan, Uganda, the United Arab Emirates, Uzbekistan, the Bolivarian Republic of Venezuela, Yemen, Zambia, Zimbabwe and the State of Palestine to the United Nations Office at Geneva." United Nations Digital Library, August 9, 2019. https://digitallibrary.un.org/record/3853509? $1 n=e n$.

Letter to President of the Human Rights Council. "Letter dated 8 July 2019 from the Permanent Representatives of Australia, Austria, Belgium, Canada, Denmark, Estonia, Finland, 
France, Germany, Iceland, Ireland, Japan, Latvia, Lithuania, Luxembourg, the Netherlands, New Zealand, Norway, Spain, Sweden, Switzerland and the United Kingdom of Great Britain and Northern Ireland to the United Nations Office at Geneva." United Nations Digital Library, July 23, 2019. https://undocs.org/A/HRC/41/G/11.

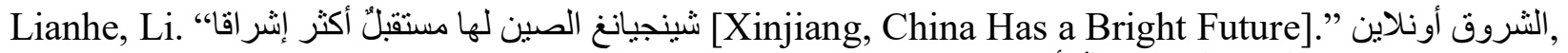

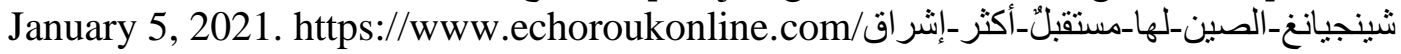

“Middle East Countries Deported Exiled Uighurs to China: Report.” Middle East Eye, 2020. https://www.middleeasteye.net/news/uighur-china-middle-east-deport-beijing.

"Nur-Sultan Wants China 'To Help Resolve Issues' Raised by Ethnic Kazakhs from Xinjiang." RadioFreeEurope/RadioLiberty, March 15, 2021. https://www.rferl.org/a/kazakhs-chinaconsulate-protesters-relatives-xinjiang-release/31147667.html.

Pannier, Bruce. "Why Are Central Asian Countries Silent About China's Uyghurs?" RadioFreeEurope/RadioLiberty, September 23, 2020. https://www.rferl.org/a/why-arecentral-asian-countries-silent-about-china-s-uyghurs-/30852452.html.

Rep. Public Opinion Poll No (77). Palestinian Center for Policy and Survey Research, September $15,2020$. https://www.pcpsr.org/sites/default/files/Poll\%2077\%20English\%20press\%20release\%20S eptember2020.pdf.

Rickleton, Chris. "After Tentative Start, Kazakhstan Is Obliterating Xinjiang Activism." Eurasianet, February 22, 2021. https://eurasianet.org/after-tentative-start-kazakhstan-isobliterating-xinjiang-activism.

Rózsa, Erzsébet N. Deciphering China in the Middle East. European Union Institute for Security Studies (EUISS), 2020. http://www.jstor.org/stable/resrep25023.

Safwat, Muhammad. “' أمل زائف.. لماذا تخلى أردو غان عن مسلمي الإيجور [False Hope... Why Did

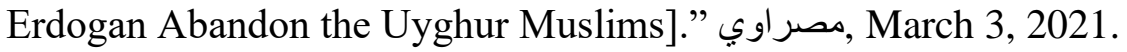

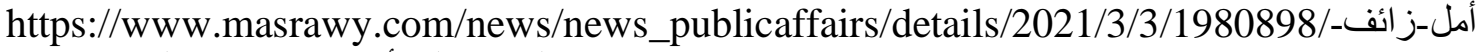
لماذا_تخلى_أردو غان-عن-مسلمي-الإيجور

Save Uighur by Justice for All, Free Uyghur Now, and US Council on Muslim Organizations. Letter to Organization of Islamic Cooperation. "Open Letter to OIC." Justice for All, December 17, 2020. https://2vwenc1h9jiauuq402mipy51-wpengine.netdna-ssl.com/wpcontent/uploads/2020/12/Open-Letter-to-OIC.pdf.

Sekin, Hanan Kamal. "Arab States And The Unrest In China's Xinjiang Province.” World Affairs: The Journal of International Issues 19, no. 3 (2015): 118-33. https://www.jstor.org/stable/48505459. 
"Seventy-Fifth Session of the General Assembly." In Third Committee Summary Record of the 3rd Meeting. New York City, 2020. https://undocs.org/en/A/C.3/75/SR.3.

Shichor, Yitzhak. "See No Evil, Hear No Evil, Speak No Evil: Middle Eastern Reactions to Rising China’s Uyghur Crackdown.” Griffith Asia Quarterly 3, no. 1 (2015). https://docs.uyghuramerican.org/pdf/629-2058-1-PB.pdf.

Shih, Gerry. "AP Exclusive: Uighurs Fighting in Syria Take Aim at China.” AP NEWS. Associated Press, December 22, 2017. https://apnews.com/article/syria-ap-top-news-riotsinternational-news-china-79d6a427b26f4eeab226571956dd256e.

Soliev, Nodirbek. "Uyghur Militancy in and beyond Southeast Asia." Counter Terrorist Trends and Analyses 9, no. 2 (2017): 14-20. http://www.jstor.org/stable/26351495.

_. "Uyghur Violence and Jihadism in China and Beyond." Counter Terrorist Trends and Analyses 11, no. 1 (2019): 71-75. https://www.jstor.org/stable/26568580.

"Statement by Ambassador Christoph Heusgen on Behalf of 39 Countries in the Third Committee General Debate." Permanent Mission of the Federal Republic of Germany to the United Nations, October 6, 2020. https://new-york-un.diplo.de/un-en/newscorner/201006-heusgen-china/2402648.

“Statement.” Global Imams Council, October 1, 2020. https://imams.org/statements/.

Wan, Christie. Rep. The Persecution of the Uyghurs and Potential International Crimes in China, August 2020. https://www.justsecurity.org/wp-content/uploads/2020/08/XinjiangReport-Version-5.0-Aug.-2020.pdf.

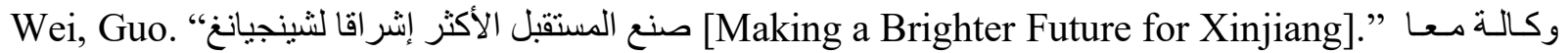
.الاخبـارية, November 19, 2020. https://www.maannews.net/articles/2024461.html.

Wern Jun, Soo, Azril Annuar, and Jerry Choong. "In KL, Hundreds of Muslims Protest against China's Treatment of Uighurs: Malay Mail.” Malaysia| Malay Mail. Malay Mail, December 27, 2019. https://www.malaymail.com/news/malaysia/2019/12/27/in-klhundreds-of-muslims-protest-against-chinas-treatment-of-uighurs/1822584.

Çaksu, Ali. "Islamophobia, Chinese Style: Total Internment of Uyghur Muslims by the People's Republic of China." Islamophobia Studies Journal 5, no. 2 (2020): 175-98. https://wwwjstor-org.ezp-prod1.hul.harvard.edu/stable/10.13169/islastudj.5.2.0175.

President of the Chinese Islamic Association: The Chinese Government Is Committed to Protecting the Religious Freedom of Muslims]." CGTN العربية , January 8, 2021. https://arabic.cgtn.com/n/BfJEAEA-CAA/FBEAcA/index.html. 
[US Official: What Is Happening to Uyghur Muslims in China Is Close to Genocide]." الجزيرة مباشر. Al Jazeera, December 17, 2020. https://mubasher.aljazeera.net/news/politics/2020/10/17/_مسؤول_أمريكي-ما-يحدث_لمسلمي الإيغور-في

[Is Turkey Colluding with China against the Muslim

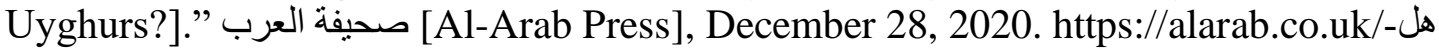

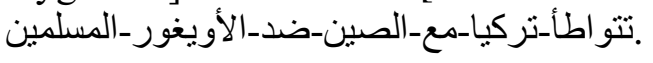

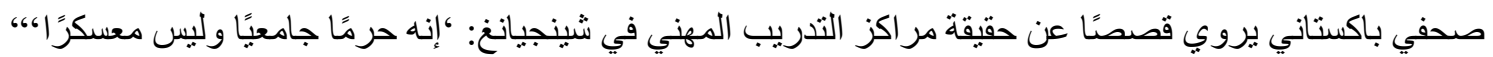
[Pakistani Journalist Tells Stories about the Reality of Vocational Training Centers in Xinjiang: 'It's a Campus, Not a Camp].” People's Daily Online, February 26, 2021. http://arabic.people.com.cn/n3/2021/0226/c31664-9822636.html.

ي'They Flaunt Stories of Rape'... A Shocking Testimony from inside the Uyghur Camps]." Al-Watan, February 19, 2021. https://alwatannews.net/article/926244/World/_يتباهون-بقصص-الاغتصاب_شهادة-مفزعة_من-داخليكرات معسكر ات_الأويغور 